\title{
Sustaining Water Systems in Rural and Small Towns in Ghana: The Role of Traditional Authorities in the Krachi West District
}

\author{
Raymond Kwasi Boasinke, \\ Department of Sociology and Anthropology, University of Cape Coast \\ Cape Coast, Ghana \\ Imoro Braimah, \\ Department of Planning Kwame Nkrumah University of Science and \\ Technology \\ Doi:10.19044/esj.2022.v18n3p10
}

Submitted: 22 July 2021

Accepted: 04 January 2022

Published: 31 January 2022
Copyright 2022 Author(s)

Under Creative Commons BY-NC-ND 4.0 OPEN ACCESS

Cite As:

Boasinke R.K.,\& Braimah I., (2022). Sustaining Water Systems in Rural and Small Towns in Ghana: The Role of Traditional Authorities in the Krachi West District European

Scientific Journal, ESJ, 18 (3), 10.

https://doi.org/10.19044/esj.2022.v18n3p10

\section{Abstract}

The sustainability of water systems in rural communities and small towns in Ghana has been a major challenge that has engaged the attention of government, Non-governmental Organisations, and academics. There have been several attempts at developing models that will ensure the sustainability of water systems in Ghana. This study examined the role of traditional authorities in the management of water systems in rural communities and small towns in the Krachi West District in the Oti Region of Ghana. Using a qualitative research design, the study purposely selected and interviewed 69 respondents. The study revealed that traditional authorities play critical roles in ensuring the sustainable management of water systems in rural communities and small towns in Ghana. It also revealed that respondents want a community management model that has traditional authorities as members of an official advisory board to the Water and Sanitation Management Teams (WSMTs). It further revealed that the traditional authorities and the WSMTs have a cordial working relationship. The study, therefore, recommends that traditional authorities should officially be recognised and their roles spelled out in the 
community management model of water systems in Ghana.

Keywords: Traditional Authorities, Water Systems, Sustainability, Rural Communities, Small Towns

\section{Introduction}

Before colonialism in Africa, the management of natural resources was mainly under the control of traditional authorities. Traditional authorities in this study refer to chiefs and their council of elders who form the traditional political structure in many communities in Africa.

Natural resources such as water bodies, wetlands, forests, gold, and wildlife were managed and regulated through traditional norms, beliefs, and practices that found expression in the cultural heritage of communities. The reverence given to traditional authorities and the awe that characterised community taboos on the use of such communal resources resulted in complete adherence to "the rules of the game" about the use of these resources (Daneel, 1996). However, colonial structures for the management of natural resources, which were based on the western models, largely weakened the influence and authority of traditional authorities in resource governance (Turner, 2000 cited in Mawere, Mabeza, and Shava, 2014). In particular, the 'new' structures for managing natural resources limited traditional authorities' participation in, authority, and control over natural resources, which have traditionally been under their jurisdiction (Scoones and Matose, 1993).

Today, many decentralised policies on natural resource management are silent on the exact roles of traditional authorities in the management of these natural resources. Mawere, Mabeza, and Shava (2014) observed the lack of clarity on the specific roles of traditional leadership in Zimbabwe in the management of natural resources as exemplified in the Traditional Leaders Act (1998). Ghana's Water Policy and the Community Water and Sanitation Agency Act did not also provide explicit roles for traditional authorities in the management of water resources. These limitations notwithstanding, members of communities on the continent recognise traditional authorities as custodians of these resources. They continue to wield some form of power over natural resources, albeit informal (Sulemana, 2010).

Broadly, traditional authorities have been recognised as agents of development. Some nation-states such as Ghana, Nigeria, and Zimbabwe have enshrined the roles of chiefs in their national constitutions. Houses and councils of chiefs have been established in some of these countries to facilitate the work of chiefs from the national to regional or provincial levels (Baloyi, 2016). Despite these attempts to involve traditional authorities in modern governance, their power in the management and control over natural resources is largely limited. The real power that they wielded during the pre-colonial era 
is lost with the introduction of new governance mechanisms that some critics perceive to be alien to traditional norms and practices (Khunou, 2011). But more importantly, these developments have generated debates about whether or not traditional authorities are crucial in the management of resources.

In Ghana, the inability of the state to explicitly legislate the roles that traditional authorities should play in the management of water and other natural resources sometimes creates a challenge of power struggles between traditional authorities and the bodies that manage such resources. This study contends that the absence of clear legislation on the explicit roles of traditional authorities in the management of such resources is at variance with how community members perceive ownership and control of their resources. Apart from anecdotal evidence that exists on traditional authorities and community management models of water systems in rural communities and small towns, there have been little systematic attempts to establish the exact roles traditional authorities play in ensuring the sustainability of such water systems. This study examined the roles that traditional authorities play in the management of water systems in the Krachi West District with the view to determine the roles of traditional authorities in the management of water systems; to assess the relationship that exists between water management bodies and traditional authorities and the implications thereof; and to determine the acceptability of a model that involves traditional authorities either directly or as members of advisory boards to the Water and Sanitation Management Teams (WSMTs).

\section{Traditional Authorities and Water Resource Management}

The role of traditional authorities in the management of natural resources in the post-colonial era has significantly reduced. The reduction is premised on the notion that traditional authorities are based on hereditary and, therefore, are undemocratic (Khunou, 2011). Khunou (2017:30-31 ) argued that traditional leaders such as the one among the Bakofeng in South Africa exhibit tenets of democracy such as the existence of checks and balances through "traditional structures that play oversight roles over their traditional authority." In Baloyi's (2016) study of traditional leadership and local government, respondents indicated that traditional leaders should be consulted in the planning of projects and should also be involved in the monitoring of such projects if rural development was to be enhanced. As far back as 1975, the United Nations Research Institute for Social Development observed that cooperatives that used existing local leadership and kinship structures in their operations usually got positive management results (United Nation Research Institute for Social Development 1975 cited in Kwashie, 2009).

Traditional authorities such as headmen, leaders of lineage as well as spiritual leaders have been identified to be playing important roles in the allocation of natural resources such as land, and the resolution of conflict 
among others (Serra, 2001; Bloom, 2000; Virtanen, 2000 cited in Mowo et al., 2013). In countries such as Mali, Burkina Faso, and Niger, similar structures exist in the management of natural resources. Informal structures that are largely based on traditional authority or leadership determine who has access to natural resources and also provide appropriate sanctions to those who do not comply with rules governing the management of natural resources (Mowo et al., 2013). Compliance with the management arrangements, which involve traditional authorities is generally high since their authority is recognised as legitimate by the people (Derbile, 2012; Mowo et al., 2013). Mowo et al. (2013) also found in their study of the highlands of Ethiopia and Tanzania that traditional leaders and councils of elders generally resolved conflicts over management and use of natural resources.

The local traditional authority, that is the chief and his council of elders, was found to be the most powerful and had the dominant influence on access and control over forest resources in the management of Ongoye forest in the KwaZulu-Natal province of South Africa (Phadima and Lawes, 2015). The community members revere and fear the chief (Inkosi) and would not want to breach the rules and regulations governing the use of forest resources so that they would be brought before the chief for disciplinary actions. Phadima and Lawes (2015) concluded that the existing management structure, which involved the chief and his council of elders as well as the local wildlife authority, was largely sustainable.

In Ghana, the traditional political structure is decentralised with a hierarchical order in terms of authority and responsibilities. At the top of the hierarchy is the paramount chief who heads all the paramountcy. Divisional Chiefs are at the next level of authority. Under the divisional chiefs are sectional chiefs or heads and household heads. Chiefs at the lower levels pay allegiance to those that are immediately above them. The chiefs have a council of elders who assist them to administer the areas under their jurisdictions. In some parts of Northern Ghana, the chief and the earth priest or Tindana coexist to ensure that the traditional duties are performed. The chief primarily plays the political functions and the earth priest who is referred to as the Tindaana or Tigatuu among the Grune and Kassem respectively plays spiritual roles such as offering sacrifices to the earth or river gods before the planting season begins (Derbile, 2012).

Derbile (2012) found that traditional authorities play critical roles in the management of irrigation facilities in some communities in two districts namely Gumbrungu in the Bongo District and Nangalkinia in the KassenaNankana East District both in the Upper East Region. These roles include giving legitimacy and authority to Water Users Associations (WUAs) in the performance of their functions; intervening to resolve protracted conflicts associated with the irrigation projects; and under certain circumstances getting 
involved in the allocation of land and water resources management to ensure fairness (Derbile, 2012). Similarly, in a study of Binaaba in the Bawku District of the Upper East Region of Ghana, Sulemana (2010) observed that traditional authorities in the area were tasked with the responsibility to inform the Ghana Irrigation Development Authorities (GIDA) about major faults on the dam such as the repair of the walls of the dam. They were also responsible for the resolution of conflicts and the determination of punishments or fines for those who breach the rules and regulations on the management of dams and other water sources in their communities. Offenders are usually fined to pay cash or livestock such as goats for polluting the dam. Traditional authorities which comprised the village heads, the chiefs, or headmen together with the members of the community designate areas for washing, watering of livestock, and drawing drinking water (Sulemana, 2010). Sulemana (2010) posited that the communities have been using traditional authorities together with Water Users Association (WUA) in water resources management. Therefore, any attempt to introduce the new Integrated Water Resource Management will render the traditional practices redundant. She further called for the modernisation of this traditional water management to ensure the sustainability of water resources.

On the community water management model, Kwashie (2009) found that traditional leadership, in this case, the clan and family heads who had an enormous influence on their kinsmen were able to ensure compliance with water regulations governing water use in the North Tongu District. He further observed that the Water and Sanitation Management Teams (WSMTs) received such support from traditional authorities because they gave due recognition and respect to such authorities.

At the District level, the District Water and Sanitation Teams play oversight and supervisory roles over community water management teams in the communities. The District Assemblies are expected to provide ongoing institutional support to the community water management teams to enhance their capacity for efficient service delivery at the community level. The WSMTs in the communities are responsible for the day-to-day management of water systems. In essence, the success of the community management model hinges on how well the WSMTs can analyse the changing environments in their operations. This will help them to be able to set the right tariffs, engage in regular maintenance, account to members of the community, adopt effective record-keeping, and generally adopt a sustainability narrative that would carry beneficiaries along to commit to the sustainable operation of their water systems.

The private sector predominantly plays roles in the engineering and technical aspect of the model by mostly drilling water systems and ensuring the proper siting of water facilities to ensure that such systems do not become non-functional after a few years of operation. Some NGOs in the subsector 
such as World Vision have enhanced the management framework by introducing the Pump Maintenance Volunteers (PMVs) within the community management model to ensure effective and prompt maintenance of water facilities (Braimah et al, 2016 ). What is clear in the institutional framework is the silence on the exact roles that traditional authorities are supposed to play in the community water management model.

\section{Underpinnings of the Community Management Model}

The community management model is underpinned by the principle of subsidiarity implied in the decentralised water governance. The decentralised governance posits that the varied needs of sub-national units are best catered for when decision-making about such needs is left in the hands of decentralised structures. Central governments are unable to diagnose such needs and are unable to respond appropriately to the needs of the local units. The theory argues that central governments are more likely to implement policies and programmes that are blanket. This disposition of central governments makes it difficult for policies and programmes to meet the diverse needs of sub-national units. The differential impacts of such policies on sub-national units present the most compelling reason for decentralisation.

Proponents of the principle of subsidiarity argue that the provision of public goods like water is likely to meet the developmental needs of local units in a decentralised system. This is so because local levels of governance are more likely to develop policies that reflect and respond to local, regional diversities, encourage greater participation, and empower local actors of the population to take charge of their own needs (Koethenbueger, 2007; Oates, 1993). Oates (1999), for example, argued that the fact that decentralised government structures are situated within the catchment areas where they are supposed to perform their roles provides an added impetus to such decentralised bodies to design and implement projects and regulations that address the specific felt-needs of the people.

This principle and its basic tenets are in sync with the decentralised rural communities and small-town water management being practiced in Ghana and other developing countries. This is because the basic institutional framework within which the decentralised water system operates recognises local specificities and provides for flexibilities to enable rural communities and small towns in the country to operate and manage their water facilities to ensure maximum efficiency and sustainability. The other advantage of this decentralised system is that it eventually empowers community members to develop a sense of self-worth and become empowered. It also allows communities to harness all the local expertise including those of traditional authorities to ensure efficient management of community programmes and projects. 
This principle and its associated management models have been criticised by academics and experts alike. The basis of the criticisms emanates from the numerous assumptions upon which they are anchored. However, these assumptions, in most cases, do not seem to hold (Scott, 2009). Scott (2009) argues that decentralisation, contrary to some perceptions, is not the remedy to all the challenges in developing countries. It has in most cases been unable to improve service delivery, enhance social cohesion and promote economic development in developing countries. In Asia, Africa, and Latin America, decentralisation did not have a significant impact on the quality and efficiency of public service. In some cases, the quality of such services has either experienced a decline or remained unchanged (Robinson, 2007 cited in Scott, 2009). This study argues that although these challenges may be experienced, they do largely stem from poor implementation. The tenets of this principle are still relevant for the management of common-pool resources.

\section{Material and Methodology}

The study was undertaken in the Krachi West District of the Oti Region in Ghana. The District was established by Legislative Instrument 20782012. It lies between latitude $0^{\circ} 10^{\prime} 0^{\prime \prime} \mathrm{W}$ and $0^{\circ} 10^{\prime} 0^{\prime \prime}$ and longitude $7^{\circ} 40^{\prime} 0^{\prime \prime} \mathrm{N}$ and $8^{\circ}$ $0^{\prime} 0^{\prime \prime} \mathrm{N}$. It is bounded to the East by the Krachi East District, to the North by the Krachi Nchumuru and the West by the Sene West District. The District's total land area is 4,169 square kilometers. About 37 percent of the entire surface area of the district is covered by water, mainly the Volta Lake and the Oti River. The district is largely rural as 81.8 percent of the population of the district lives in rural areas (Ministry of Finance and Economic Planning, 2016).

About sanitation, the district has pit latrines and public toilet facilities, but with no facilities for the disposal of liquid waste, so residents resort to throwing waste indiscriminately (GSS 2014). The dominant mode of water source is boreholes fitted with hand pumps. Figure 1 below shows a map of the Krachi West District showing some settlements. 


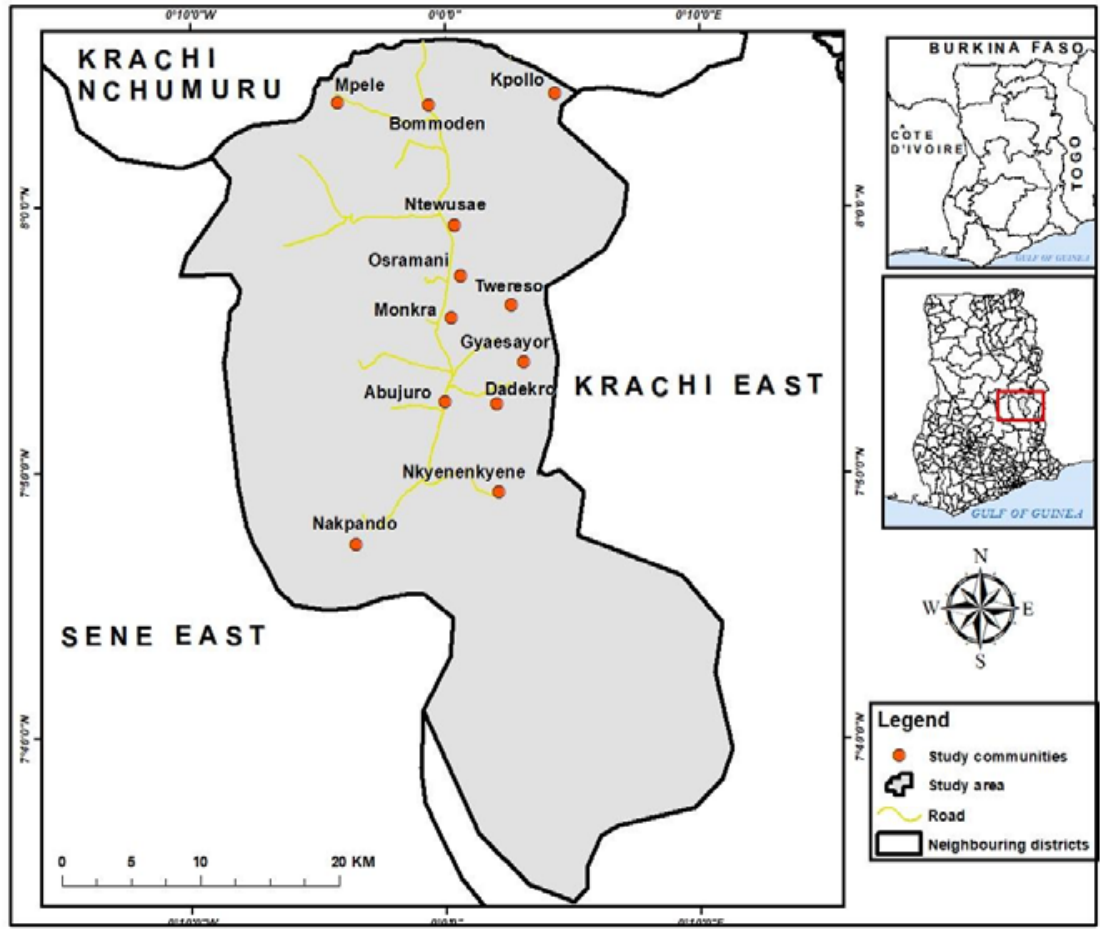

Figure 1: A map of the Krachi West District showing some settlements

Source: Cartographic Unit, Department of Geography and Regional Planning, UCC (2018)

\section{Study Design and Sampling Technique}

A total of 69 respondents were purposively selected comprising 2 members of the District Water and Sanitation Team (DWST), 19 members of traditional authorities, and 48 members of the WSMTs. The 48 members of WSMTs were selected from twenty communities in the study area. They were primarily made up of chairpersons, secretaries, and treasurers of WSMTs in the communities. One member of each traditional authority, mainly the chief, was selected and interviewed. Nineteen instead of 20 members of traditional authorities were selected because two of the communities that were randomly selected for this study had one chief. Two members of the DWST were selected because they were the most active members of the team.

Interview guides were used to elicit information from respondents. To ensure that the information was reliably captured, the responses were simultaneously written down and tape-recorded with prior permission. On average, the interviews lasted for about 40 minutes each. The recorded interviews were transcribed. Themes were identified and based on the themes, the results and discussions were done. Compelling voices that succinctly captured particular themes were quoted verbatim. 


\section{Findings and Discussion}

\section{Sustainability of Water Systems: The place of traditional authorities}

The interviews revealed that traditional authorities play key roles including the following: ensuring that the WSMTs were transparent and accountable to the communities; providing financial support in critical times; taking over the entire management of water facilities in the absence of a WSMT in their communities; helping with the resolution of conflicts and enforcing by-laws on water systems. In the Tatakope community, for instance, the water system was being managed by the headman and his elders who constituted the traditional authority in the community. According to them, the members of the previous committee have either migrated or died and since then, they had assumed the management of the water system. They had managed the water system for nearly two years in the absence of a WSMT. This was an exceptional case that came to the researcher as a serendipitous finding since the normal practice was for the DWST to assist the community in getting a WSMT.

In some communities such as Abujuro, it was revealed that traditional authorities sometimes gave financial support to the WSMT when money was not readily available for the maintenance of the water systems. According to a member of the Ntewusae WSMT, the traditional authorities provide them with a fraction of the money they generate from the sale of lands and from leasing out a piece of land to a telecommunications company to erect a mast. This, according to him, has provided the WSMT with sufficient revenue to maintain their water systems. Due to this support, the WSMT can procure spare parts for the water systems in advance, which enables them to promptly fix their water systems when they break down. This kind of support reflects the level of mutual trust and cooperation that exists between the WSMT and the traditional authorities in those communities. The traditional authorities were willing to support their water management systems if they had more financial resources. A member of traditional authorities from the Abujuro community expressed the following thoughts:

I think the traditional authorities could have done better if we had enough money. We could have mobilized ourselves to have our hand pumps fixed or appealed to the relevant stakeholders in the water sector to give us additional hand pumps.

Notwithstanding the roles that the traditional authorities are playing in the management of the communities' water systems, they felt that they could have done better if they had the means to do so. In other words, they were willing to enhance their support for the communities to ensure that they had a constant and uninterrupted water supply. The diverse roles played by the traditional authorities in the community management of water systems reflect the fact that historically the management of water and other natural resources were 
spearheaded by the members of the traditional authorities, especially chiefs. The study revealed that traditional authorities were concerned with the sustainability of their water systems and were determined to ensure that their water systems served the communities well. The roles that were identified as being played by traditional authorities lie at the heart of the sustainability of water systems. The findings are in line with the position of Kwashie (2009) that traditional leadership was able to ensure compliance with water regulations governing water use in the North Tongu District. These findings also confirm the views of Derbile (2012) and Suleimana (2010) that traditional authorities generally help to ensure compliance with rules by imposing fines on offenders and resolving conflicts that arise from the use of community irrigation systems. The discussions thus far show that it will be practically impossible to ensure sustainable management of water systems without the involvement of traditional authorities. They are pivotal to the operation and maintenance of the community water system that it will be inconceivable to implement such a model without them. This probably explains why Suleimana (2010) cautioned against attempts to exclude them from community-based management models.

\section{The Relationship between Traditional Authorities and WSMTs}

The study also sought to establish the relationship that exists between the traditional authorities and the WSMTs in the communities. The analysis of the views of traditional authorities indicated that all of them had cordial relationships with the WSMTs in their communities. Even in the few communities where they were not satisfied with the work of the WSMTs, they still indicated that they had a very cordial relationship with them. They indicated that they work in close collaboration with the WSMTs in the communities. They often discussed issues concerning the management of the water systems together with the WSMTs to find solutions to problems. They also empower the committees to enforce the by-laws and to deal with anyone who refuses to pay the water user fees prescribed by the community. One of the most repetitive expressions in their narratives is "they are our children". This indicates a strong cordial relationship between them and the WSMTs.

The WSMTs, on the other hand, confirmed this relationship. They all recognised traditional authorities as to the superior authorities as far as their work was concerned. They also saw the traditional authorities as the custodians of the water systems and saw themselves as people who had volunteered to work for them. Consequently, they did not take any major decisions without first seeking the consent of the traditional authorities. Normally, one would expect that the communities see the District Assembly as the custodian of the water system. However, this was not the case. They rather saw traditional authorities as those who hold the water systems in trust 
for the communities. This shows how highly members of the WSMTs regard their traditional authorities in the study area. All the members of the WSMTs interviewed were of the view that they had a cordial relationship with the traditional authorities. Members of the WSMTs explained, among other things, that they were united with the traditional authorities in their work as managers of the water systems. They saw the traditional authorities as their appointing authority in the management of the water systems of their communities and therefore, had cordial working relationships with them. Factors such as these together with the fact that traditional authorities gave them the needed attention and cooperation were what led all of the water managers to conclude that they had a very cordial relationship with them.

Members of WSMTs were of the view that such a working relationship with traditional authorities greatly helped to enhance their work as managers of the water systems in their communities. The WSMTs received wise counsel or advice from the traditional authorities in times of difficulties. Also with their help, the WSMTs were able to exact compliance from recalcitrant community members who refuse to pay for water user fees or fail to comply with the by-laws governing the usage of water in the community. The traditional authorities sometimes lend money to some of the WSMTs when money is not readily available for the maintenance of their water systems. About how such a cordial relationship helps them, a member of the WSMT in the Twereso community made this statement:

We work in close collaboration with them; when there is a challenge and they can assist, they do so. We also help the community when the need arises. For example, there was a time when a rainstorm destroyed the roof of our community school building so the Member of Parliament of the area supported us with roofing sheets for the building to be reroofed. While the work was going on, the WSMT decided to support the community by providing food for the artisans. They advise and encourage us to be decorous and tolerant when we are dealing with members of the community.

Given the importance of the roles played by traditional authorities, it was therefore not surprising that all the WSMTs had a cordial relationship with their traditional authorities. This cordial relationship produced mutual trust between traditional authorities and WSMTs which has helped to enhance the sustainability of water systems. From the analysis, it is quite obvious that the cordial relationship between stakeholders in the management of communal resources is of considerable importance. The mutual trust and respect it brings enhances productivity and ensures that quick decisions are taken to resolve challenges. Such a working relationship between traditional authorities and the water management bodies was what gave traditional authorities the impetus to even provide additional funding to ensure the sustainable operation 
and maintenance of water systems, as was observed in Ntewusae. Overall, the study showed that a cordial working relationship was helpful for the activities of the WSMTs. These findings buttress the need to recognise traditional authorities as an integral part of the development agenda. This kind of relationship that exists at the decentralised level between these two key actors is the management of water systems would have been difficult in a centralised system where WSMTs are appointed from "outside". This finding is in line with Kwashie's (2009) study in the Volta Region where he established that WSMTs that gave traditional authorities due to recognition in their operation were able to achieve better outcomes in the management of water systems.

\section{Traditional Authorities as Official Members of WSMTs}

The study sought to find out whether traditional authorities themselves would want to officially be made a part of the WSMTs in their communities given the roles they play in the management of the water systems. The analysis of the responses of the traditional authorities showed that the majority of them were opposed to the idea of making traditional authorities an official part of WSMTs in their communities. The commonest themes that ran through their reason for taking such a position were that the WSMTs were doing a good job with the management of the water systems and so there was no need for that. The other explanation was that they were satisfied with the current arrangement and their roles as de facto advisors and supervisors. The few who indicated their willingness to be part of the committee indicated that their inclusion in the committees will help to enhance the work of the committee. The main theme that ran through their explanations was that traditional authorities were revered by members of the community and therefore if such elders were made part of the WSMTs it will help to ensure compliance with rules and by-laws governing water systems in the communities. In line with this, a few communities have representatives of traditional authorities who serve on the WSMTs. Communities such as Adankpa and Kwakuae have already selected representatives from traditional authorities to serve on WSMTs. In Kwakuae, the secretary to traditional authorities is also a member of the WSMT in the community. It was only four out of the 19 members of traditional authorities that supported the inclusion of traditional authorities as an official part of water management bodies in their communities. Three of these communities have already appointed their representatives to be part of committees and boards that are managing water systems. Analysis of the views of WSMTs on whether or not traditional authorities should be made an official part of the WSMTs showed that the majority did not support the view that traditional authorities be made an official part of the WSMTs. Their reasons are summed up into these three themes. First, traditional authorities were old and the WSMTs also receive a lot of insults from the members of the 
communities. Second, traditional authorities have a very busy schedule and might not be active members of the WSMTs; and third, traditional authorities could be dictatorial in their decision-making when they are made an official part of the WSMTs. The third explanation is in line with the argument of Khonou (2011) that those who oppose traditional authorities often do so because such authorities are based on hereditary and therefore are undemocratic. It could be inferred that the first two reasons seek to protect the sanctity of the chieftaincy institution as well as the health of the members of traditional authorities.

A WSMT member in the Osramani community made the following observation about these reasons:

I personally would not have any difficulty with traditional authorities being made an official part of the WSMT at all. However, the reason why we would not want them to be officially part of the team is that there are a lot of insults and abuses in our line of work and this is below the dignity of traditional authorities. How can a young man insult a whole Odikro? For me, I am young and I can tolerate that, but I would not want them to experience that. Besides, when we are abused or insulted, they defend us a lot.

The third reason relates to the fear that traditional authorities could take over the entire work of the water management bodies because they hold enormous influence and authority. In other words, there was the fear that members of traditional authorities could be dictatorial in their dealings with the WSMTs, and their presence could intimidate the young ones and prevent them from expressing themselves freely. Despite the enormous roles that the District Water and Sanitation Team members indicated that the traditional authorities play in ensuring the success of the community management of water systems, they did not support the inclusion of traditional authorities as official members of WSMTs. They proposed that their activities should be limited to the performance of advisory duties in the communities. One of the members who was a representative from the Environmental Health Office expressed his views as follows:

It is not advisable to make the traditional authorities a part of those who manage the day-to-day affairs of the water systems in the communities. This is so because when they are involved and there are issues where will you take the case to? For example, when there is embezzlement of funds and the chief is involved, it will be difficult to deal with such an issue. Moreover, the chief could make the work of the technical officers difficult when they offer professional advice; they could lord it over them. Therefore, their roles should be limited to serving as supervisors or advisors to the WSMTs. 


\section{Traditional Authorities as Members of an Advisory Board for WSMTs}

The study sought to test the possibility of a model which would include traditional authorities as part of an advisory board to the WSMTs in the study area. Among traditional authorities, the responses showed that all but one member of the traditional authorities interviewed were in support of the suggestion that the advisory board could include the traditional authorities and other opinion leaders in the community. One of the study communities, Osramani, has a similar board, which meets to make decisions on challenges that affect the community and advise the water board in the community. A member of the traditional authorities in the Kwakuae community was of the view that such a board will be consistent with the already existing roles that they were playing:

I think we are already doing the work of such an advisory board. This is so because when difficult situations arise in the management of the water systems, we are the ones that the committee consults for advice. However, some of the members of traditional authorities want such a board to be expanded to include some other opinion leaders in the communities. A member of the traditional authorities in the Abujuro community explained it this way:

There is the need for such an advisory board. We could choose a fivemember advisory board from the lineages in the community with the chief and the queen mother being part of it. Those who would serve on the board should be opinion leaders from the lineages together with traditional authorities.

The only member of traditional authorities who was opposed to such a board came to that conclusion because he thought that the WSMTs were not doing anything wrong that would necessitate the formation of such an advisory board.

From the analysis, respondents were not in favour of a model that would include traditional authorities in the day-to-day management of water systems in the communities due to the reasons highlighted above. None of the reasons provided gave an inkling of incompetence on the part of traditional authorities; they had to do with socio-cultural dynamics within the communities. However, they overwhelmingly support any model that would include them as members of an advisory board to the WSMTs. As it was observed by some of the members of traditional authorities, the creation of such an advisory board would be consistent with the roles that they were already playing about water systems. It was also observed that the members of the WSMTs in the study area tended to support the creation of an advisory board made up of traditional authorities. This would be a board that would provide the needed advice to the WSMTs in the communities about the best way to sustainably manage water systems in the communities. Some also 
thought that when such an advisory board is added to the formal structure of the Community Management Model, it will help to formalise the roles of traditional authorities who have always served as advisors to the water management bodies in the communities. The DWST as indicated above preferred an advisory board to make traditional authorities an official part of the day-to-day running of the water systems in the communities. This finding will help to formally alter the structure of the current community management model in the communities to include traditional authorities and other opinion leaders as the formal advisory board to the WSMTs. The establishment of such a board will also bring about role clarity and resolve any potential power struggle between traditional authorities and WSMTs.

\section{Conclusions and Recommendations}

The ability of communities to sustainably manage their water system is one of the critical issues that underlie the achievement of the Sustainable Development Goals on water by 2030. This study examined the roles that traditional authorities play to ensure a sustainable community management model of rural communities and small towns in the Krachi West District in Ghana.

The study has established that traditional authorities play very significant roles in ensuring the sustainable management of water systems in the Krachi West District. Their roles range from ensuring compliance with bylaws, lending money to communities for maintenance, and providing good counsel to WSMTs among others. These roles have helped to ensure the sustainability of water systems in the district. It can be concluded that in the country's quest to ensure sustainable models in the management of water systems, the roles of traditional authorities should be harnessed. The reverence that traditional authorities enjoy within communities in Ghana makes it possible for them to ensure that by-laws and other regulations governing water use are enforced.

It is therefore recommended that the current community water management model be modified to include an advisory board composed of traditional authorities. The study espouses that such an official inclusion will ensure role clarity and help to preserve the cordial relationship that exists between traditional authorities and WSMTs.

\section{References:}

1. Baloyi, T.B. (2016). The role of traditional leadership in local government. A research report submitted to the Faculty of Commerce, Law and Management, University of Witwatersrand. 
2. Daneel, M.L. (1996). Environmental reform: A new venture of Zimbabwe's traditional custodians of land. Journal of Legal Pluralism and Unofficial Law 28(37-38), 347- 376.

3. Derbile, E.K. (2012). Water user association and indigenous institutions in the management of community based irrigation schemes in northeastern Ghana. European Scientific Journal, 8(26), 118-135.

4. Ghana Statistical Service (2014). Ghana Living Standard Survey Round 6: Poverty profile in Ghana (2005-2013). Accra: Ghana.

5. Koethenbeurger, M. (2007). Revisiting the decentralisation theoremOn the role of externalities. Cesifo Working Paper, 2128, 1-10.

6. Khunou, S.F. (2017). The customary anatomy of the traditional governance of the Bafokeng traditional community: The implications of the constitutional recognition of hereditary headmanship.PER/PELJ2017(20)doi:http://dx.doi.org/10.171 59/1727- 3781/2017/v20i0a3270.

7. Khunou, S.F. (2011). Traditional leadership and governance: legislative environment and policy development in a democratic South Africa. International Journal of Humanities and Social Science 1(9), 278-290.

8. Kwashie, H.B.K. (2009). The management and sustainability of water supply facilities in rural communities: Lessons from the Volta Region. Ghana Social Science Journal, 5\&6 (1\&2), 188-216.

9. Mawere, M., Mabeza, C.M.\&Shava, T. (2014). Traditional authority in community-based natural resource management (CBNRM): A critical investigation of the role of traditional authority in fisheries management in GacheGache communal lands of Kariba, Zimbabwe. Fisheries and Aquaculture Journal 5(2), 1-7 doi:10.4172/2150- 3508.1000093.

10. Ministry of Finance and Economic Planning (2016). The composite budget of the Krachi West District Assembly for the 2016 fiscal year. Accra: Ministry of Finance and Economic

a. Planning.

11. Mowo, J.G., Adimassu, Z., Catacutan, D., Tanui, J., Masuki, K. \&Lyamchai, K. (2013). The importance of local traditional institutions in the management of natural resources in the highlands of East Africa. Human Organisation, 72(2):154-163.doi: 10.17730/humo.72.2.e1x3101741127x35.

12. Oates, D.E. (1993). Fiscal decentralisation and economic development. National Tax Journal, 46:237-243.

13. Oates, W.E. (1999). An essay on fiscal federalism. Journal of Economic Literature, 37, 1120- 1149. 
14. Phadima, J. \& Lawes, M.J. (2015). The role of traditional authority in the use and management of forest resources at the Ongoye forest. Message posted at http://www.researchgate.net/publication/266229224).

15. Scoones, I. \& Matose, F. (1993). Local woodland management: constraints and opportunities for sustainable resource use. World Bank Technical Paper- INOR PUBLICATIES.

16. Sulemana, T. A. (2010). The role of traditional authorities in water resource management in Binaaba, Bawku West District. A thesis submitted to the Department of Planning Management, Faculty of Planning and Land Management, University for Development Studies. 